\title{
FIRST RECORD OF THE ALBORAN DRAGONET, PROTOGRAMMUS ALBORANENSIS (ACTINOPTERYGII: CALLIONYMIFORMES: CALLIONYMIDAE), FROM THE BALEARIC ISLANDS (WESTERN MEDITERRANEAN)
}

\author{
Ronald FRICKE ${ }^{1}$ and Francesc ORDINES ${ }^{2}$
}

${ }^{1}$ Lauda-Königshofen, Germany

${ }^{2}$ Instituto Español de Oceanografia, Centre Oceanogràfic de les Balears, Palma de Mallorca, Spain

Fricke R., Ordines F. 2017. First record of the Alboran dragonet, Protogrammus alboranensis (Actinopterygii: Callionymiformes: Callionymidae), from the Balearic Islands (western Mediterranean). Acta Ichthyol. Piscat. 47 (3): 289-295.

Background. The Alboran dragonet, Protogrammus alboranensis Fricke, Ordines, Farias et García-Ruiz, 2016, was originally described based on four specimens from Alboran Island, Spain, south-western Mediterranean, collected in 2014 and 2015. This species was previously considered to be endemic to Alboran Island. A surprising new record of this rare species from the Balearic Islands is reported here.

Material and methods. A specimen of $P$. alboranensis was collected from a bottom trawl sampling carried out at $159 \mathrm{~m}$ depth in the north of Mallorca, Balearic Islands, during the survey MEDITS_ES05_17 in June 2017. The specimen (a male) has been deposited in the collection of the Hebrew University of Jerusalem (HUJ).

Results. Protogrammus alboranensis is recorded from the Balearic Islands for the first time; the specimen is examined, described and illustrated.

Conclusions. The new record confirms that the species is more widely distributed in the western Mediterranean than previously expected. This type of study is needed to know about the distribution and habitats of this rare species, to support possible conservation measures. The depth of collection and the benthic habitat in the sampling location were similar to those in the location of the original description of the species (Alboran Island): deep shelf bottoms with biogenic coarse sand and presence of abundant dead shells in both locations. The colouration of the species is highly mimetic with that type of sediments indicating that this is probably the ideal habitat for the species.

Keywords: fish, Spain, Balearic Sea, distribution, endemism

\section{INTRODUCTION}

Dragonets (family Callionymidae) are a group of benthic living fishes occurring in the upper 900 metres of all temperate, subtropical, and tropical oceans of the world, and a few species are found in estuarine and freshwater habitats (Fricke 1983a). They are characterised by a depressed body, a triangular head when seen from above, the large eyes, situated dorsally on the head, the presence of a preopercular spine which is bearing additional spinules and/or serrae, the gill opening reduced to a small pore, absent swim bladder, two dorsal fins (the first with thin, flexible spines, the second with soft rays), and jugular pelvic fins which are separated from each other, but each connected with the pectoral-fin base by a membrane. The Atlantic species of the family were revised by Fricke (unpublished*), who distinguished 18 valid species from the area, including seven species from the western Mediterranean. Nakabo and Hartel (1999) raised Foetorepus dagmarae (Fricke, 1985) and Foetorepus valdiviae (Trunov, 1981) to the species level and described Foetorepus goodenbeani Nakabo et Hartel, 1999 (here classified in genus Synchiropus). Fricke (2002), in a checklist of callionymid fishes, listed a worldwide total of 182 valid species in 10 genera. Subsequently, several additional species were described, including Protogrammus alboranensis Fricke, Ordines, Farias et García-Ruiz, 2016 from the Alboran Sea, southwestern Mediterranean (Farias et al. 2016). Callionymus sanctaehelenae Fricke, 1983 was synonymized with Callionymus bairdi Jordan, 1888 by Fricke (2002). Synchiropus sechellensis Regan, 1908 was reported as a Lessepsian migrant in the eastern Mediterranean by Gökoğlu et al. (2014), and Diplogrammus randalli

\footnotetext{
" Correspondence: Dr Ronald Fricke, Im Ramstal 76, 97922 Lauda-Königshofen, Germany, phone: +49 9343 600801, e-mail: (RF) ronfricke@web.de, (FO) xisco.ordinas@ba.ieo.es

${ }^{* *}$ Fricke R. 1986. Zoogeographie der Callionymidae (Osteichthyes: Perciformes) des Atlantischen Ozeans. Diploma thesis, Technische Universität Braunschweig, Germany.
} 
Fricke, 1983, another Lessepsian migrant in the eastern Mediterranean, by Seyhan et al. (2017).

During the recent MEDITS bottom trawl survey in the Balearic Islands in June 2017, a single male specimen of Protogrammus was discovered, which represents a new record of $P$. alboranensis, and significantly expands the distribution range of this rare species. The specimen is described in the present paper. The species is compared with allied species, and its distribution is discussed.

\section{MATERIALS AND METHODS}

The new specimen of Protogrammus alboranensis was collected from a bottom trawl sampling carried out at $159 \mathrm{~m}$ depth during the MEDITS_ES05_17 survey that took place around the Balearic Islands in June 2017 (for more specifications on sampling and design see Bertrand et al. 2002) (Fig. 1). The bottom trawl used was a GOC73, which had an average horizontal and vertical openings ranging from 16 to $21 \mathrm{~m}$ and 2.4 to $3.1 \mathrm{~m}$, respectively, and was equipped with $10 \mathrm{~mm}$ diamond cod end mesh. Hauls lasted from 20 to $60 \mathrm{~min}$ of effective sampling (bottom time) depending on depth stratum, at a speed of 3 knots. Two additional beam trawl samples were carried out in the sampling location where the $P$. alboranensis appeared but no other individual of the species was caught. The beam trawl was a Jennings type ( $2 \mathrm{~m}$ and $0.5 \mathrm{~m}$ of horizontal and vertical openings, respectively, with $5 \mathrm{~mm}$ cod end mesh) similar to that used to take the samples off Alboran Island in which the individuals in the original description of the species were collected. The sediment and epibenthos appeared in these two beam trawl samples were used to complete the description of the habitat where the new specimen was found.

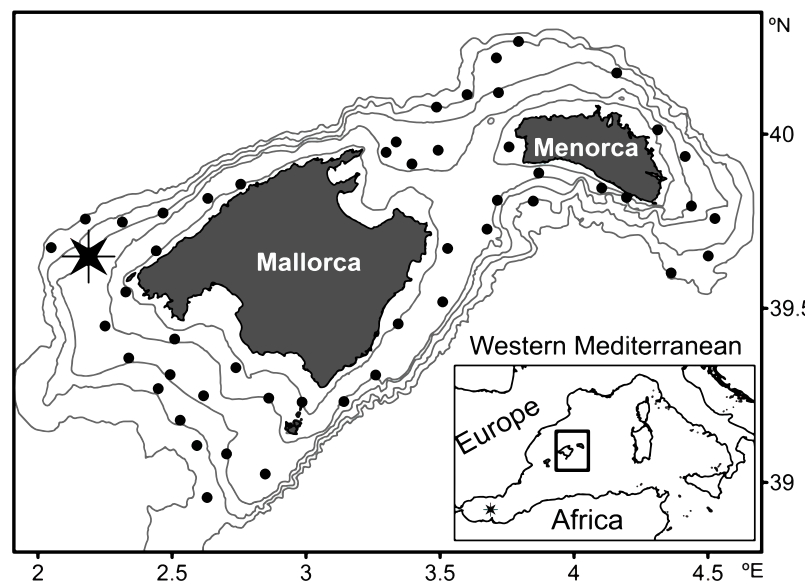

Fig. 1. Map of the study area - the Balearic Islands; the black dots mark the bottom trawl sampling sites carried out during the MEDITS_ES05_17 survey; the star marks the bottom trawl sample site in which the newly recorded specimen of Protogrammus alboranensis was caught; another star in the inset marks the locality where the holotype $P$. alboranensis was caught off Alboran Island; the isobaths shown represent 50, 100, 200, 500, and $800 \mathrm{~m}$ depths
Materials of Protogrammus alboranensis from the Balearic Islands are deposited in the National Natural History Collection, Hebrew University, Jerusalem (HUJ). Counts and measurements followed Hubbs and Lagler (1947), fin-ray counts followed Fricke (1983b). The standard length is abbreviated SL, Central European Standard Time is abbreviated CEST. the classification follows Eschmeyer et al. (2017), references according to Fricke (2017), collection acronyms follow Fricke and Eschmeyer (2017). The fish collection of the İzmir Katip Çelebi University, Turkey is abbreviated IKC.

Materials of Protogrammus alboranensis from the western Mediterranean (other than the type series from Alboran Island) reported in the present paper as a new record include the following: HUJ 20672 (1 male, 52.5 $\mathrm{mm}$ SL), Balearic Islands, Spain, northwest of Mallorca, 39³8.93' N 2॰11.33'E, $159 \mathrm{~m}$ depth, bottom trawl, R/V Miguel Oliver, F. Ordines, Cruise MEDITS_ES05_17, St. 191, 11 June 2017, 11:56 h CEST.

Comparative materials of species of Protogrammus include the following (all specimens known of the genus):

\section{Protogrammus alboranensis Fricke, Ordines,} Farias et García-Ruiz, 2016: CFM IEOMA 5557 (holotype, male, $50.2 \mathrm{~mm} \mathrm{SL}$ ), Spain, Alboran Sea, $35^{\circ} 56^{\prime} 36^{\prime \prime} \mathrm{N}, \quad 3^{\circ} 05^{\prime} 55^{\prime \prime} \mathrm{W} ; \quad$ CFM_IEOMA 5558 (1 paratype, male, $48.1 \mathrm{~mm} \mathrm{SL}$, same data as the holotype); SMF 35715 (1 paratype, male, $36.5 \mathrm{~mm} \mathrm{SL),} \mathrm{Spain,}$ Alboran Sea, $35^{\circ} 56^{\prime} 19^{\prime \prime} \mathrm{N}, 3^{\circ} 05^{\prime} 48^{\prime \prime} \mathrm{W}$; SMF 35716 (1 paratype, female, $24.5 \mathrm{~mm} \mathrm{SL}$, same data as SMF 35715).

Protogrammus antipodus Fricke, 2006: SMNS 23698 (holotype), Lifou, Loyalty Islands, New Caledonia, 200-220 m depth; MNHN 2006-1235 (1 paratype), Lifou, Loyalty Islands, New Caledonia, 70-130 m depth.

Protogrammus sousai (Maul, 1972): MMF 22877 (holotype), Great Meteor Seamount, 315-320 m depth; MMF 22389 (1 paratype), Great Meteor Seamount, 310 m depth; MMF 22843a (1 paratype), Great Meteor Seamount; MMF 22843b (1 paratype), Great Meteor Seamount.

\section{RESULTS}

Family CALLIONYMIDAE

Protogrammus Fricke, 1985

Protogrammus alboranensis Fricke, Ordines, Farias et García-Ruiz, 2016

Figs. 2, 3, Table 1

Description. Fin-ray counts: D IV + viii, 1; A vii, 1; P1 ii, 18, ii (total 22); P2 I, 5; C (i), i, 7, ii, (i). Morphometric measurements and proportions are given in Table 1.

Body elongated and depressed. Head depressed. Branchial opening dorsal in position. Preopercular spine very small; preopercular spine formula

$$
-\frac{1}{-} 1
$$


with single point on its dorsal margin similar in size to the main tip, both curved and pointing upwards; ventral margin and base smooth, without points (Figs. 2 B, 3 C). Lower half of operculum with free flap of skin, but upper half connected with body. Urogenital papilla elongated. Lateral line reaching from preorbital region to end of fourth branched caudal fin ray (counted from above), up curved below end of first dorsal fin base and beginning of second dorsal fin base, then slightly down curved, again up curved above end of anal fin base, with number of short dorsal and ventral branches along sides of body, and with long preopercular branch; lines of opposite sides interconnected across occipital region, but not across dorsal part of caudal peduncle. Sides of body between lateral line and anal fin base having ventrolateral fold of skin consisting of 11 short, disconnected segments not reaching caudal peduncle, which are reduced and difficult to detect.

First and second spines of first dorsal fin long, filamentous, much longer than first ray of second dorsal fin. Rays of second dorsal fin unbranched, last divided at its base, upper branch elongate and filamentous, reaching beyond caudal fin base when laid back. Rays of anal fin unbranched, last divided at its base, lower branch elongate and filamentous, reaching beyond caudal fin base when laid back. Pectoral fin reaching to base of second anal-fin ray when laid back. Pelvic fin large, fourth ray elongate, reaching to base of third anal fin membrane when laid back. Caudal fin elongated, without filaments.

Colours of live specimen shown in Fig. 3 A, B (male): Head pale brownish grey with several golden spots on cheeks, preopercle, opercle, and lower pectoral-fin base. Occipital region rosy. Body pale grey, with four dark brown dorsal patches, two of them (one on nape and other coinciding with first half of second dorsal fin) darker than rest, and slender yellow reticule on sides of body. First dorsal fin distally dark, with blackish blotch distally on third membrane. Second dorsal fin having four thin, yellow, horizontal lines. Anal fin distally blackish. Lower one-third of caudal fin and lower distal margin blackish; upper parts of caudal fin with golden bars and blotches. Pectoral fin pale; pelvic fin having greyish area distally on third and fourth rays.

Distribution and habitat. Western Mediterranean Sea, Spain, Balearic Islands, north of Mallorca (Fig. 1). Outside the area, off Alboran Island (south-western Mediterranean).

Both locations share similar depths and habitats. In the north of Mallorca, Protogrammus alboranensis was collected at $159 \mathrm{~m}$ depth on a coarse sand bottom with presence of abundant empty shells of the brachiopod Gryphus vitreus and also dead remains of Gracilechinus acutus and Spatangus purpureus (Echinodermata) (Fig. 4), whereas in Alboran Island it was found on a similar bottom at $113 \mathrm{~m}$ depth, although in that location the empty shells and remains mainly corresponded to the deep sea oyster shell Neopycnodonte cochlear. The epibenthic community (living organisms) in the Balearic Islands sampling location was dominated by $G$. vitreus and the polychaete Hyalinoecia tubicola, but G. acutus and $S$. purpureus were also present (Fig. 4). The most abundant fish species syntopic with $P$. alboranensis in the Balearic Islands were Scyliorhinus canicula (Linnaeus, 1758); Chelidonichthys cuculus (Linnaeus, 1758); Arnoglossus rueppelii (Cocco, 1844); and Arnoglossus imperialis (Rafinesque, 1810).

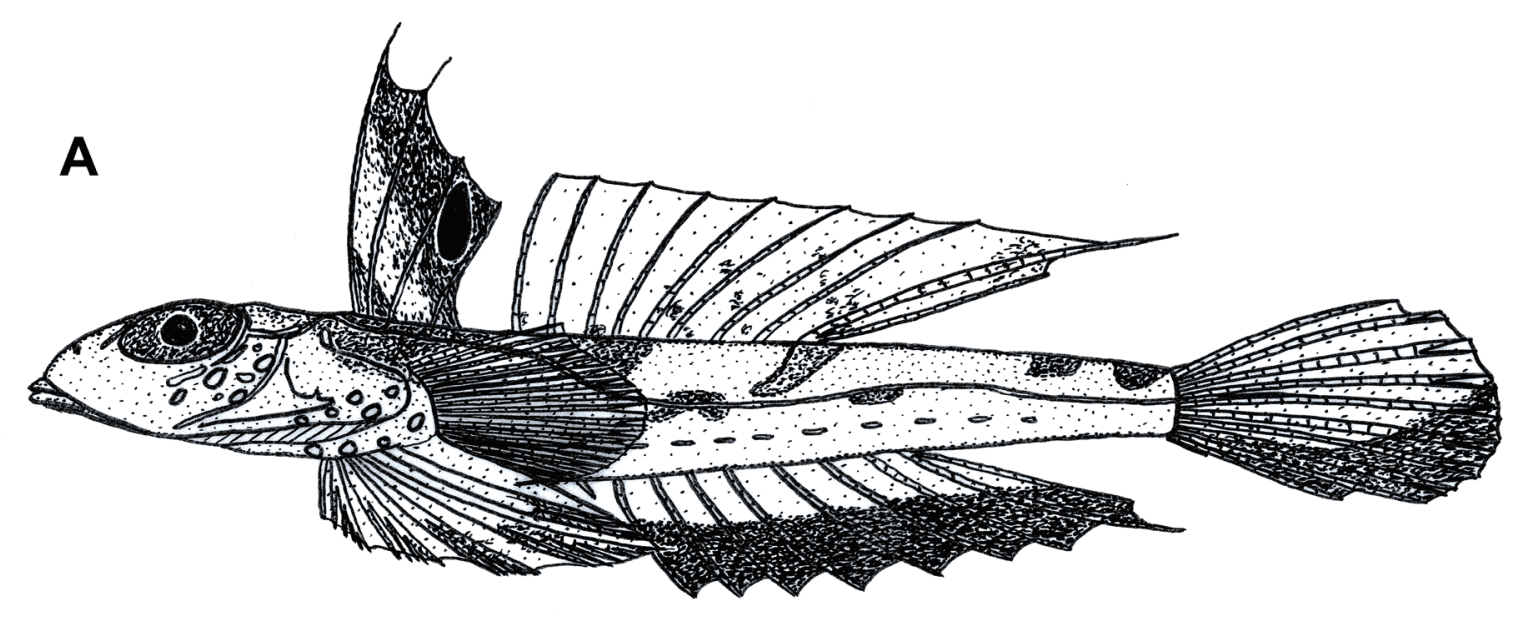

B

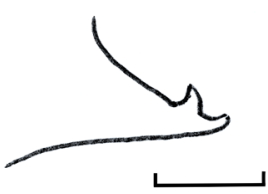

Fig. 2. Protogrammus alboranensis, HUJ 20672, male, $52.5 \mathrm{~mm}$ SL, western Mediterranean Sea, Spain, Balearic Islands, north of Mallorca; lateral view; scale bar $10 \mathrm{~mm}(\mathbf{A})$; left preopercular spine; scale bar $1 \mathrm{~mm}(\mathbf{B})$ 


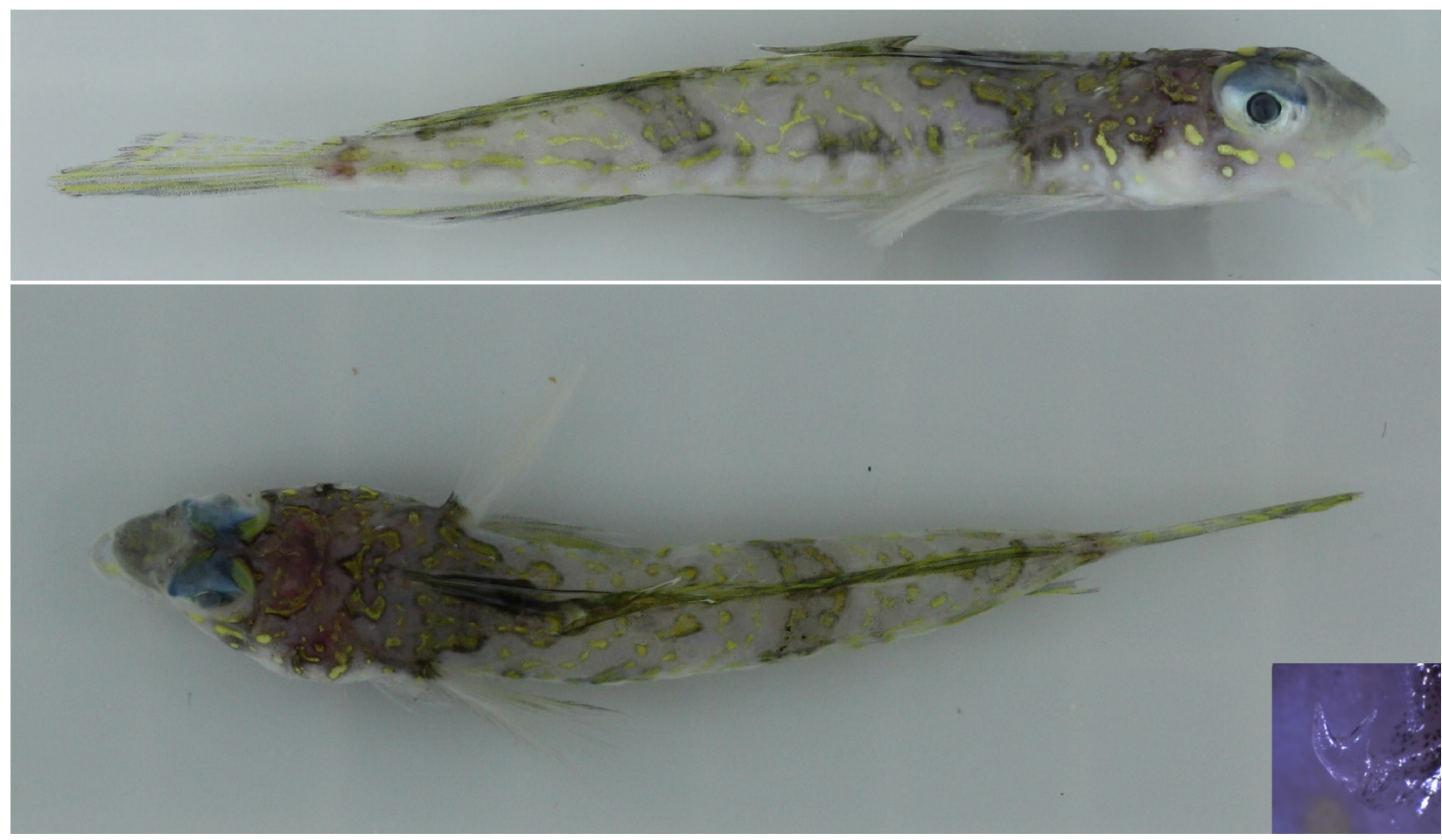

Fig. 3. Protogrammus alboranensis, HUJ 20672, male, $52.5 \mathrm{~mm}$ SL, western Mediterranean Sea, Spain, Balearic Islands, north of Mallorca; photographs of specimen immediately after collection; lateral view (A); dorsal view (B); right preopercular spine $(\mathbf{C})$

Table 1

Protogrammus alboranensis, HUJ 20672, 52.5 mm SL, Mediterranean Sea, Balearic Islands, north of Mallorca; measurements and proportions

\begin{tabular}{|c|c|c|c|c|c|}
\hline Parameter & $\begin{array}{c}\text { Measurement } \\
{[\mathrm{mm}]}\end{array}$ & $\begin{array}{c}\text { Proportion in } \\
\text { SL }\end{array}$ & $\begin{array}{c}\text { Percentage of } \\
\text { SL }\end{array}$ & $\begin{array}{c}\text { Proportion in } \\
\text { HL }\end{array}$ & $\begin{array}{c}\text { Percentage of } \\
\text { HL }\end{array}$ \\
\hline Standard length (SL) & 52.5 & & & & \\
\hline Caudal-fin length & 15.3 & 3.4 & 29.1 & & \\
\hline Predorsal(1) length & 14.8 & 3.6 & 28.2 & & \\
\hline Predorsal(2) length & 25.4 & 2.1 & 48.4 & & \\
\hline Preanal length & 25.7 & 2.0 & 49.0 & & \\
\hline Prepelvic fin length & 13.1 & 4.0 & 25.0 & & \\
\hline Prepectoral fin length & 18.4 & 2.8 & 35.0 & & \\
\hline Head length (HL) & 13.0 & 4.0 & 24.8 & & \\
\hline Body depth & 7.1 & 7.4 & 13.5 & & \\
\hline Body width & 8.2 & 6.4 & 15.6 & & \\
\hline Caudal-peduncle length & 13.3 & 4.0 & 25.3 & & \\
\hline Caudal-peduncle depth & 2.6 & 20.2 & 5.0 & & \\
\hline Length of first spine of first dorsal fin & 13.8 & 3.8 & 26.3 & & \\
\hline Length of second spine of first dorsal fin & 12.4 & 4.2 & 23.6 & & \\
\hline Length of third spine of first dorsal fin & 8.2 & 6.4 & 15.6 & & \\
\hline Length of fourth spine of first dorsal fin & 6.7 & 7.8 & 12.8 & & \\
\hline Length of first ray of second dorsal fin & 7.9 & 6.6 & 15.0 & & \\
\hline Length of last ray of second dorsal fin & 16.6 & 3.2 & 31.6 & & \\
\hline Length of first anal-fin ray & 6.6 & 8.0 & 12.6 & & \\
\hline Length of last anal-fin ray & 11.9 & 4.4 & 22.7 & & \\
\hline Pectoral-fin length & 10.6 & 5.0 & 20.2 & & \\
\hline Pelvic-fin length & 16.5 & 3.2 & 31.4 & & \\
\hline Orbit diameter & 5.5 & & & 2.4 & 10.5 \\
\hline Preorbital length & 3.7 & & & 3.5 & 7.0 \\
\hline Bony interorbital & 0.8 & & & 16.2 & 1.5 \\
\hline Upper-jaw length & 4.2 & & & 3.1 & 8.0 \\
\hline
\end{tabular}




\section{DISCUSSION}

The dragonet specimen trawled north of Mallorca (HUJ 20672) was recognised as a species of Protogrammus due to the presence of a free flap of skin present on the lower half of the opercle only, and a ventrolateral fold of skin consisting of short, disconnected segments. It was compared with the three known species of the genus (Table 2), and was found to agree in all important characters with $P$. alboranensis. Just a few less important proportions differed slightly from that species, but these are considered to fall within the range intraspecific variation of male specimens. That variation range is not well known, as previously only three male specimens of P. alboranensis have been collected.

Protogrammus alboranensis was first discovered and described by Fricke et al. in Farias et al. (2016: 53, figs. 2-3) based on four specimens from Alboran Island, Spain. These have been the only specimens known of the species, collected with beam trawls in 2014 and 2015, at a depth of $113 \mathrm{~m}$, on a coarse sand bottom with deep sea
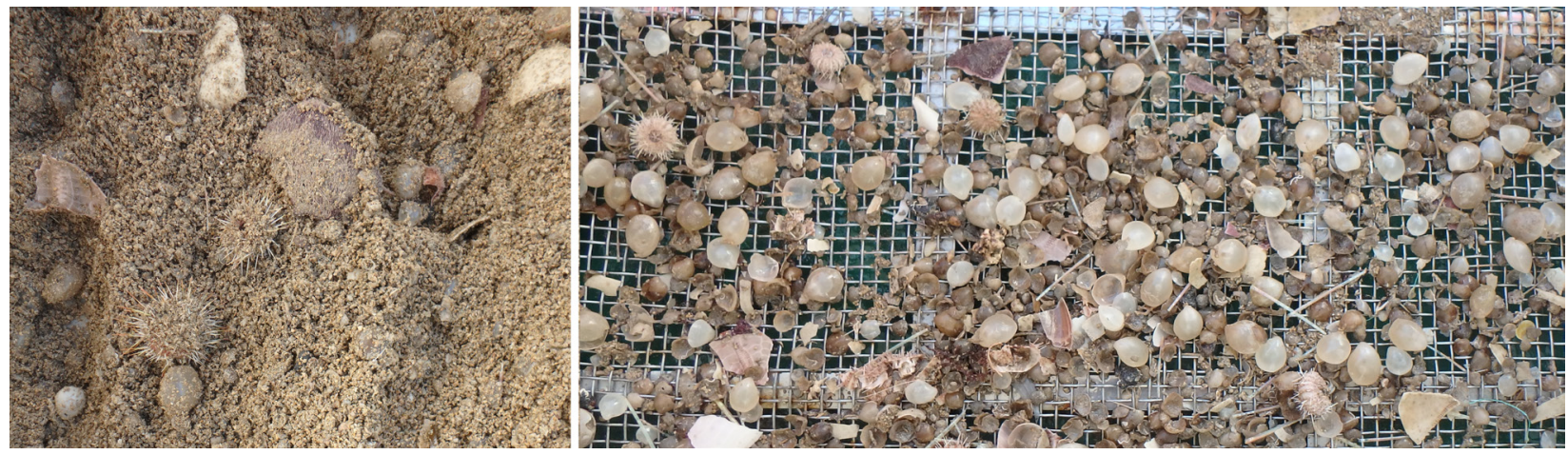

Fig. 4. Photographs of the sediment and epibenthic fauna that appeared in the beam trawl samples carried out in the sampling station where Protogrammus alboranensis was caught in the north of Mallorca, Balearic Islands; beam trawl sample before sieving showing the coarse sand sediment and some alive individuals of the brachiopod Gryphus vitreus, and the echinoderms Gracilechinus acutus and Spatangus purpureus (A); beam trawl sample after sieving through a $1 \mathrm{~cm}$ sieve with abundant dead shell remains of the $G$. vitreus and alive individuals of $G$. vitreus, the polychaete Hyalinoecia tubicola and G. acutus (B)

Table 2

Protogrammus alboranensis, HUJ 20672, $52.5 \mathrm{~mm}$ SL, Mediterranean Sea, Balearic Islands, north of Mallorca; comparison with the other known specimens of Protogrammus; differences to the Mallorca specimen of $P$. alboranensis are given in bold face

\begin{tabular}{|c|c|c|c|c|}
\hline Character & $\begin{array}{l}\text { P. alboranensis, } \\
\text { Mallorca, } \\
\text { Mediterranean }\end{array}$ & $\begin{array}{l}\text { P. alboranensis, } \\
\text { Alboran Island, } \\
\text { Mediterranean }\end{array}$ & $\begin{array}{l}\text { P. sousai, Meteor } \\
\text { Seamount, } \\
\text { NE Atlantic }\end{array}$ & $\begin{array}{l}\text { P. antipodus, Lifou, } \\
\text { Loyalty Island, } \\
\text { SW Pacific }\end{array}$ \\
\hline First dorsal-fin spines & IV & IV & IV & IV \\
\hline Second dorsal-fin rays & viii, 1 & viii, 1 & viii, 1 & vii, 1-viii, 1 \\
\hline Anal-fin rays & vii, 1 & vii, 1 & vii, 1 & vi, 1 \\
\hline Total pectoral-fin rays & 22 & $20-22$ & 20-21 & $20-25$ \\
\hline Preopercular spine, dorsal points & 1 & 1 & 1 & $3-7$ \\
\hline Preopercular spine, main tip & Upcurved & Upcurved & Straight & Straight \\
\hline Preopercular spine, base & No spine & No spine & No spine & Antrorse spine \\
\hline 1st spine of dorsal fin, male & $\begin{array}{l}\text { Longer than } 1 \text { st } \\
\text { D2 ray, filamentous }\end{array}$ & $\begin{array}{l}\text { Longer than } 1 \text { st } \\
\text { D2 ray, filamentous }\end{array}$ & $\begin{array}{l}\text { As long as 1st D2 ray, } \\
\text { not filamentous }\end{array}$ & $\begin{array}{l}\text { Longer than 1st } \\
\text { D2 ray, filamentous }\end{array}$ \\
\hline 2nd spine of dorsal fin, male & $\begin{array}{l}\text { Longer than } 1 \text { st } \\
\text { D2 ray, filamentous }\end{array}$ & $\begin{array}{l}\text { Longer than } 1 \text { st } \\
\text { D2 ray, filamentous }\end{array}$ & $\begin{array}{l}\text { As long as 1st D2 ray, } \\
\text { not filamentous }\end{array}$ & $\begin{array}{l}\text { Longer than 1st } \\
\text { D2 ray, filamentous }\end{array}$ \\
\hline 3rd spine of dorsal fin, male & $\begin{array}{l}\text { As long as } 1 \text { st } \mathrm{D} 2 \text { ray, } \\
\text { not filamentous }\end{array}$ & $\begin{array}{l}\text { As long as } 1 \text { st } \mathrm{D} 2 \text { ray, } \\
\text { not filamentous }\end{array}$ & $\begin{array}{l}\text { As long as } 1 \text { st } \mathrm{D} 2 \text { ray, } \\
\text { not filamentous }\end{array}$ & $\begin{array}{l}\text { Longer than 1st } \\
\text { D2 ray, filamentous }\end{array}$ \\
\hline $\begin{array}{l}\text { Segments of ventrolateral fold of } \\
\text { skin }\end{array}$ & 11 & $9-11$ & $18-22$ & 7 \\
\hline Male anal fin & Distally dark & Distally dark & Pale & $\begin{array}{l}\text { With distal dark } \\
\text { spots }\end{array}$ \\
\hline Head length in SL & 4.0 & $3.0-4.3$ & $3.7-4.6$ & $3.5-3.6$ \\
\hline Predorsal(2) length in SL & 2.1 & $1.9-2.4$ & 2.4 & $2.0-2.1$ \\
\hline Preanal length in SL & 2.0 & $1.7-2.0$ & $1.8-2.0$ & $1.8-1.9$ \\
\hline Preorbital length in head (male) & 3.5 & $3.5-3.9$ & 3.6 & 4.4 \\
\hline
\end{tabular}


oyster shell remains (Neopycnodonte cochlear). The most abundant fish species syntopic with $P$. alboranensis were Arnoglossus thori Kyle, 1913; Callionymus maculatus Rafinesque, 1810; Diplecogaster bimaculata (Bonnaterre, 1788); Serranus cabrilla (Linnaeus, 1758); and Serranus hepatus (Linnaeus, 1758) (see Farias et al. 2016). Protogrammus alboranensis was supposed to be endemic to Alboran Island in the south-western Mediterranean, geographically separated from the north-eastern Atlantic species Protogrammus sousai (known only from Meteor Seamount, northwest of Madeira) (Fricke 1985, Fricke in Whitehead et al. 1986, Fricke 2016); potential barriers to dispersal were discussed by Farias et al. (2016).

The depth and habitat where the species was found in the Balearic Islands share high similarity with the bottoms from where the species was originally described. It was also found on the deep shelf at a similar depth, $159 \mathrm{~m}$, and the benthic habitat in the sampling location was characterised by the presence of coarse sand and abundant dead shells. However, in the Balearic Islands these shells mainly belonged to dead individuals of the brachiopod Gryphus vitreus, which also dominated the alive fraction of the epibenthic community, instead of Neopycnodonte cochlear which dominated in the location off Alboran Island. Syntopic demersal fish species had also similarities, with Arnoglossus spp. being among the most important species in both areas. But similarities between the only two locations where the species have been found so far go further than those related to the type of benthic habitat and accompanying species. Both the Balearic Islands and Alboran Island are isolated marine areas, far from the influence of mainland rivers that could supply important amounts of terrigenous sediments. In both areas, the continental shelf bottoms are characterized by the presence of important epibenthic communities which develop on biogenic coarse sand sediments which dominate, due to the reduced supply of terrigenous sediments, down to the shelf break where muddy bottoms replace them (Ordines and Massutí 2009, Gofas et al. 2014). The coloration of Protogrammus alboranensis seems to be highly adapted to these types of biogenic sediments in which the individuals are perfectly mimetic, indicating it is probably its ideal habitat.

The new record of Protogrammus alboranensis from the Balearic Islands demonstrates that this species is more widespread in the western Mediterranean Sea, and expands the known distribution range by more than $600 \mathrm{~km}$ towards the north-east; this is the second Mediterranean region for which the presence of this extremely rare species could be confirmed. A total of 11 species of callionymid fishes is currently known to occur in the Mediterranean Sea, including three Lessepsian immigrants of Red Sea origin which have invaded through the Suez Canal. Protogrammus alboranensis and Callionymus reticulatus Valenciennes, 1837 are the only species confined to the western Mediterranean. Both species have probably immigrated from the Atlantic; while C. reticulatus still occurs in the north-eastern Atlantic, P. alboranensis is there replaced by the similar species $P$. sousai.
The distribution of the genus Protogrammus is still very unusual. Besides the two Northern Hemisphere species in the north-eastern Atlantic and western Mediterranean, P. sousai and P. alboranensis, while $P$. antipodus is only found in the Southern Hemisphere in the south-western Pacific (Fricke 2006). In between, two other genera with complete ventrolateral folds of skin are distributed, Chalinops in the western Atlantic and Diplogrammus in the Indo-West Pacific. Both of the other genera live in shallow water, Chalinops at 2-27 m, Diplogrammus at 0-34 m, while Protogrammus is known from depths of 113-310 m. Reasons for this relict distribution in deeper water were discussed by Farias et al. (2016). These authors suggested that the ancestors of Protogrammus have been in the area for a long time, and appeared in the region before the closure of the Tethys Sea. During the Messinian Salinity Crisis in the late Miocene, Mediterranean species such as the ancestors of Protogrammus alboranensis were probably in exile in the eastern Atlantic; they immigrated into the Mediterranean again after it filled with Atlantic Ocean water (Fricke unpublished ${ }^{*}$ ). The speciation event between $P$. sousai and $P$. alboranensis may have happened after this re-immigration, since the Strait of Gibraltar now forms a barrier to dispersal of Protogrammus larvae. Callionymid fish larvae, which are found in shallow water close to the surface only, can only disperse with the prevailing current from the eastern Atlantic to the Mediterranean, but usually not in the other direction against the current (Fricke unpublished*). The deep counter current runs too deep to support the dispersal of larval Protogrammus. While it is likely that the ancestral Protogrammus formerly had a wider distribution in the eastern Atlantic, today's distribution range of $P$. sousai around seamounts west of Madeira is too far away from the Strait of Gibraltar to support the western Mediterranean with larval fish dispersal. This barrier prevents the exchange of larvae, so the evolution of separate species east and west of the barrier is enhanced.

\section{ACKNOWLEDGEMENTS}

We would like to thank the following persons for information, loan of specimens, or permission to examine specimens under their care (comparative materials): Patrice Pruvost (MNHN), Manuel Biscoito, the late Günther Edmund Maul (MMF), Tilman Alpermann, Wolfgang Klausewitz, Friedhelm Krupp, and Horst Zetzsche (SMF). We are grateful to Daniel Golani (HUJ) who provided a catalogue number for the specimen described herein.

The MEDITS_ES05_17 survey is part of the DEMBAGOL_DOS project (Spanish Institute of Oceanography). This project has been co-funded by the EU through the European Maritime and Fisheries Fund (EMFF) within the National Program of collection, management and use of data in the fisheries sector and support for scientific advice regarding the Common Fisheries Policy. 


\section{REFERENCES}

Bertrand J.A., Gil de Sola L., Papaconstantinou C., Relini G., Souplet A. 2002. The general specifications of the MEDITS surveys. Scientia Marina 66 (Suppl. 2): 9-17.

DOI: $10.3989 /$ scimar.2002.66s29

Eschmeyer W.N., Fricke R., Van der Laan R. (eds.) 2017. Catalog of fishes. California Academy of Sciences, San Francisco. [Electronic version; Accessed on 4 July 2017.] http://researcharchive.calacademy. org/research/ichthyology/catalog/fishcatmain.asp.

Farias C., Ordines F., García-Ruiz C., Fricke R. 2016. Protogrammus alboranensis n. sp. (Teleostei: Callionymidae), a new species of dragonet from the Alboran Sea, western Mediterranean Sea. Scientia Marina 80 (1): 51-56.

DOI: $10.3989 /$ scimar.04340.13A

Fricke R. 1983a. Revision of the Indo-Pacific genera and species of the dragonet family Callionymidae (Teleostei). Theses Zoologicæ. Vol. 3. Verlag von J. Cramer, Braunschweig, Germany.

Fricke R. 1983b. A method of counting caudal fin rays of actinopterygian fishes. Braunschweiger Naturkundliche Schriften 1 (4): 729-733.

FrickeR. 1985. Protogrammus, a new genus of callionymid fishes, with a redescription of $P$. sousai from the eastern Atlantic. Japanese Journal of Ichthyology 32 (3): 294-298.

DOI: $10.1007 / \mathrm{BF} 02905433$

Fricke R. 2002. Annotated checklist of the dragonet families Callionymidae and Draconettidae (Teleostei: Callionymoidei), with comments on callionymid fish classification. Stuttgarter Beiträge zur Naturkunde, Serie A, Biologie 645: 1-103.

Fricke R. 2006. Two new species and a new record of dragonets from New Caledonia (Teleostei: Callionymidae). Stuttgarter Beiträge zur Naturkunde, Serie A, Biologie 696: 1-14.

Fricke R. 2016. Suborder Callionymoidei. Callionymidae. Dragonets. Pp. 2810-2824. In: Carpenter K.E., de Angelis N. (eds.) The living marine resources of the eastern Central Atlantic. Volume 4. Bony fishes part 2 (Perciformes to Tetraodontiformes) and sea turtles. FAO, Rome.
Fricke R. (ed.) 2017. References in the Catalog of fishes. California Academy of Sciences, San Francisco. [Electronic version; Accessed on 4 July 2017.] http:// researcharchive.calacademy.org/research/ichthyology/ catalog/fishcatmain.asp.

Fricke R., Eschmeyer W.N. 2017. Guide to fish collections in the Catalog of fishes. California Academy of Sciences, San Francisco. [Electronic version; Accessed on 4 July 2017.] http://researcharchive.calacademy. org/research/Ichthyology/Catalog/collections.asp.

Gofas S., Goutayer J., Luque Á.A., Salas C., Templado J. 2014. Espacio marino de Alborán. Areas de estudio del proyecto LIFE+ INDEMARES. Fundación Biodiversidad del Ministerio de Agricultura, Alimentación y Medio Ambiente, Madrid, Spain.

Gökoğlu M., Özvarol Y., Fricke R. 2014. Synchiropus sechellensis Regan, 1908 (Teleostei: Callionymidae), a new Lessepsian migrant in the Mediterranean Sea. Mediterranean Marine Science 15 (2): 440-442.

DOI: $10.12681 / \mathrm{mms} .906$

Hubbs C.L., Lagler K.F. 1947. Fishes of the Great Lakes region. Bulletin, Cranbrook Institute of Science, No. 26. Bloomfield Hills, MI, USA.

Nakabo T., Hartel K. E. 1999. Foetorepus goodenbeani: A new species of dragonet (Teleostei: Callionymidae) from the western North Atlantic Ocean. Copeia 1999 (1): 114-121.

Ordines F., Massutí E. 2009. Relationships between macro-epibenthic communities and fish on the shelf grounds of the western Mediterranean. Aquatic Conservation: Marine and Freshwater Ecosystems 19 (4): 370-383.

DOI: 10.1002 /aqc.969

Seyhan D., Irmak E., Fricke R. 2017. Diplogrammus randalli (Pisces: Callionymidae), a new Lessepsian migrant recorded from the Mediterranean Sea. Mediterranean Marine Science 18 (1): 1-3.

DOI: $10.12681 / \mathrm{mms} .1948$

Whitehead P.J.P., Bauchot M.-L., Hureau J.-C., Nielsen J., Tortonese E. 1986. Fishes of the northeastern Atlantic and the Mediterranean. Volume 3. UNESCO, Paris.

Received: 7 July 2017 Accepted: 6 August 2017 Published electronically: 30 September 2017 